\title{
Citizens' Views of Private Security Guards in Hungary: A Preliminary Analysis $^{1}$
}

\section{NALLA, Mahesh K. ${ }^{2}$ - CHRISTIÁN László ${ }^{3}$}

One of the features of emerging markets is the potential for an expanded role for the private police - a substitute crime prevention strategy in times of rapid decline in state funding of public police, has become commonplace in countries around the world. While much research has explored the citizens' assessment of police officers, we know little about how the public perceives private security guards (PSGs). In this paper, we assess the citizens' perceptions of private security guards. Drawing data from 800 citizens in Budapest, Hungary, we assess if factors such as citizens' contact experience and their perceptions about the guards' professionalism, imagery and civility influences their views about their obligation to obey private police officers. Findings of policy implications are discussed.

\section{Introduction}

The expansion in the employment of private security guard industry has become commonplace in developed and developing economies. In many instances, the number of private security guards (PSGs) outnumber the personnel employed in the national police forces in many countries in Eastern Europe ${ }^{4}$ and elsewhere. ${ }^{5}$ The demand for PSGs is partly explained by a strong economic growth and coupled with a lack of public confidence in public law enforcement in many of the developed and emerging economies. ${ }^{6}$ The demand for PSGs is also explained by the important role they play in securing personnel and assets in the corporate sector, and large private businesses where much public life takes place. ${ }^{7}$

The work was commissioned by the National University of Public Service under the priority project PACSDOP-2.1.2CCHOP-15-2016-00001 entitled "Public Service Development Establishing Good Governance" in the Ludovika Workshop.

2 Mahesh K. NALLA, PhD, Professor, School of Criminal Justice, Michigan State University orcid.org/0000-0002-6337-7468, nalla@msu.edu

3 László CHRISTIÁN, PhD, Police Colonel, Associate Professor, National University of Public Service, Faculty of Law Enforcement, Department of Private Security and Local Governmental Law Enforcement orcid.org/0000-0001-9809-4890, christian.laszlo@uni-nke.hu

Nalla-Gurinskaya (2017)

Nalla-Wakefield (2013)

Cao-Zhao (2005)

Shearing-Stenning (1983) 
Hungary is no exception. The country has experienced a significant growth in the employment of PSGs in recent decades after the disintegration of the Soviet Union. According to the 2013 Confederation of European Security Services in Europe (CoESS) report, in 2014 there were a total 3,000 to 3,500 private security guard companies in Hungary, though the Hungarian Bodyguards, Property Protection and Private Detectives Association (MBVMSZ) listed approximately 300 companies and employed about 22,000 guards. In 2010, the EuroObserver noted that Hungary had over 100,000 private security guards far outnumbering the total number of police officers: with 105 guards versus 40 police officers per 100,000 population. ${ }^{8}$ Data from CoESS and other related sources suggest similar differences in the employment disparity in public and private police personnel. ${ }^{9}$ The minimum requirements to work as a private security guard are: they must be 18 years of age, be a legal resident in the country and have no criminal record. ${ }^{10}$ In addition, guards must complete the state-mandated training requirements consisting of 320 hours of course requirement followed by a required state mandated refresher training every 5 years. ${ }^{11}$ The governmental regulation 87/1995 was the only official document that governed the functioning of the industry until the introduction of Act. IV of 1998. This regulation was superseded by Act CXXXIII of 2005 and two other acts - Act CLIX of 1997 for armed security guards and Act CXX of 2012 for special law enforcement personnel. ${ }^{12}$ The state police has the oversight responsibilities over the private security industry in terms of issuing licenses and certificates.

Despite this industry's fast paced growth, the presence of significant numbers in private security personnel relative to the number of police personnel, and, the fact that many citizens interact with PSGs as social regulators, we know very little of public attitudes relating to security guards, their work, professionalism and general satisfaction with private police in Hungary. Thus, the aim of this research is to assess the Hungarian citizens' perceptions of PSGs, with specific focus on the nature of security work, guards' professionalism, effectiveness and overall satisfaction with security guards.

\section{Citizens' Attitudes towards Private Security Guards}

\section{Method}

Data for the present study was drawn from a sample of college students attending two universities, Pázmány Péter Catholic University and the National University of Public Service in Budapest in 2015. The students were from the faculties of Law and Political Science (PPCU) and Faculty of Law Enforcement (NUPS) and many were non-traditional students. A survey was developed based on prior research conducted, exploring

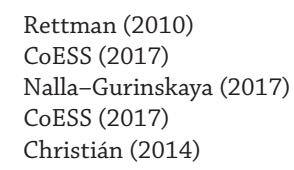


citizen perceptions of PSGs in one Eastern European country, Slovenia, ${ }^{13}$ and the Netherlands. ${ }^{14}$ The survey was initially written in English and later translated into Hungarian. The sample was first administered to 10 students to test the validity and reliability of the translations. Questions were written to elicit citizen response on a wide range of issues that include the nature of security work, professionalism, their effectiveness and civility and satisfaction with guard services. The survey was designed to measure opinions on a 5-point Likert Scale where a response of 0 represented "strongly disagree" and 4 represented "strongly agree" on various constructs drawn from prior literature noted above. These responses were recoded as 1 (strongly disagree) to 5 (strongly agree) at the time of data entry for easier interpretation of the findings. Questions were designed to capture the respondents' opinions regarding security guards' professionalism (e.g. PSGs are trained, well-trained to handle complex problems, etc.); effectiveness (e.g. private security guards do a good job preventing crime in the neighbourhood, etc.); civility (e.g. private security guards respect citizen rights, guards treat citizens with respect, etc.); and, satisfaction (PSGs do a good job in working with people to solve problems, etc.). In addition, we also asked the respondents if they had contact with PSGs, and if yes, whether their interaction was positive or negative. The goal was to assess if these factors influenced their perceptions on various dimensions of security guards' work and behaviour.

From each of the selected universities, the same instructor was to allowed to administer the survey to the students in their other classes. A total number of 30 such classes were chosen for survey administration. The number of students in each class ranged from 25 to 100. A total of 1,200 surveys were given to students of which 800 agreed to take part (response rate of approximately $83 \%$ ).

\section{Findings}

\section{Respondent Characteristics}

Respondent characteristics are presented in Table 1. The majority of the respondents were female $(\mathrm{N}=392,49 \%)$ relative to male $(\mathrm{N}=368,46 \%)$. A little over $28 \%(\mathrm{~N}=225)$ of all the respondents were 20 years or less, about a third ( $\mathrm{N}=247,30.9 \%)$ were in the age group of 21 to 23 years, and the remaining $(\mathrm{N}=328,41 \%)$ were over 24 years of age. The majority of the respondents $(\mathrm{N}=526,65.8 \%)$ have some college education or presumably currently are college students, while 81 (10.1\%) indicated they were college graduates. Most of the remaining 148 respondents (18.5\%) reported to have completed high school. Two hundred and thirty-four respondents (29.1\%) were single and 230 (28.7\%) were in a dating relationship. A third of all of the respondents (33.3\%) were either married or cohabiting and a small number $(\mathrm{N}=22,2.8 \%)$ noted they were divorced, widowed, or separated. The majority of the respondents are unemployed

\footnotetext{
13 Nalla et al. (2006)

14 van Stead-Nalla (2010)
} 
( $\mathrm{N}=495,61.9 \%)$. Regarding family income, $32 \%$ of the respondents' monthly family income was average, $19.9 \%$ came from families earning above average income, and about $37.5 \%$ noted a monthly family income below average. Of the total respondents, only $229(28.6 \%)$ reported to have had contact with a private security guard. Of those who had contact, over $75 \%$ of the respondents reported to have had a positive experience or observed the guards' behaviour to be positive.

Table 1: Demographic Characteristics of the Respondents $(N=800)$

\begin{tabular}{|c|c|c|c|c|}
\hline Variable & Description & N/\%* & Mean & S. D. \\
\hline \multicolumn{5}{|c|}{ Demographic Characteristics } \\
\hline \multirow[t]{3}{*}{ Gender } & & & 0.52 & 0.50 \\
\hline & Male & $368 / 46.0$ & & \\
\hline & Female & $392 / 49.0$ & & \\
\hline \multirow[t]{4}{*}{ Age } & & & 26.68 & 10.77 \\
\hline & $<20$ & $225 / 28.1$ & & \\
\hline & $21 \sim 23$ & $247 / 30.9$ & & \\
\hline & $24>$ & $328 / 41.0$ & & \\
\hline \multirow[t]{5}{*}{ Education } & & & 2.89 & 0.61 \\
\hline & Some high school & $19 / 2.4$ & & \\
\hline & High school graduate & $129 / 16.1$ & & \\
\hline & Some college & $526 / 65.8$ & & \\
\hline & College graduates & $81 / 10.1$ & & \\
\hline \multirow[t]{5}{*}{ Relationship } & & & 2.10 & 0.88 \\
\hline & Single/Never married & $234 / 29.3$ & & \\
\hline & Dating & $230 / 28.7$ & & \\
\hline & Married/Cohabiting & $266 / 33.3$ & & \\
\hline & Divorced/Widowed/Separated & $22 / 2.8$ & & \\
\hline \multirow[t]{3}{*}{ Working } & & & 0.34 & 0.47 \\
\hline & Unemployed & $495 / 61.9$ & & \\
\hline & Employed & $253 / 31.6$ & & \\
\hline \multirow[t]{3}{*}{ Income } & & & 1.80 & 0.78 \\
\hline & Below Average & $300 / 37.5$ & & \\
\hline & Average & $256 / 32.0$ & & \\
\hline \multicolumn{5}{|c|}{ Personal interaction with the private security officer } \\
\hline & & \multicolumn{2}{|c|}{ Yes } & $229(28.6)$ \\
\hline & & \multicolumn{2}{|c|}{ No } & $521(65.1)$ \\
\hline \multicolumn{5}{|c|}{ Experience with the private security guard was } \\
\hline & & \multicolumn{2}{|c|}{ Negative } & $50(21.8)$ \\
\hline & & \multicolumn{2}{|c|}{ Positive } & $179(78.2)$ \\
\hline \multicolumn{5}{|c|}{ Private security guard behaviour was } \\
\hline & & \multicolumn{2}{|c|}{ Negative } & $54(23.6)$ \\
\hline & & \multicolumn{2}{|c|}{ Positive } & $174(76.0)$ \\
\hline
\end{tabular}

* May not add up to 100 percent due to missing cases.

Source: Drawn by the author 


\section{Private Security Guards' Professionalism}

Table 2 displays findings on respondents' perceptions of security guards' professionalism. Three questions were asked of the respondents to reflect on their concept of guards' professionalism. The five response categories ranging from strongly disagree to strongly agree were merged into three categories with strongly disagree and disagree as one category, neutral or unsure as the second category, and finally agree and strongly agree as the third category. In addition, the mean scores and standard deviation are also displayed in the table. Less than a third of the respondents (29.2\%) felt guards are well trained, are professional (26.8\%) and are able to handle complex problems (27.8\%). The majority of the respondents were ambivalent on security guards' professionalism: training (38.2\%), professional (40.4\%), and ability to handle complex problems (37.8\%). Overall, the findings suggest that the public does not appear to have a good sense about PSGs' professionalism.

Table 2: Citizen views on private security guards professionalism $(N=800 ; N / \%)$

\begin{tabular}{|l|c|c|c|c|c|c|}
\hline \multicolumn{1}{|c|}{ Professionalism } & N & Disagree & Neutral & Agree & Mean & S. D. \\
\hline Private Security Guards are: & & & & & & \\
\hline Well trained & 753 & $245 / 31.6$ & $288 / 38.2$ & $229 / 29.2$ & 2.92 & 1.03 \\
\hline Are professional & 752 & $247 / 32.8$ & $304 / 40.4$ & $201 / 26.8$ & 2.87 & 1.00 \\
\hline $\begin{array}{l}\text { Are trained well to handle } \\
\text { complex problems }\end{array}$ & 751 & $258 / 34.4$ & $284 / 37.8$ & $209 / 27.8$ & 2.9 & 1.07 \\
\hline
\end{tabular}

* Mean score on a 5-point scale ( 1 = strongly disagree to 5 = strongly agree $)$.

Source: Drawn by the author

\section{Private Security Guards' Effectiveness}

A second set of questions was framed to understand the college students' responses regarding the effectiveness of the role security guards play. Findings are displayed in Table 3. Two questions were asked that capture the effectiveness concept. Only about two-fifths of all the respondents do a good job maintaining order (42.2\%) and respond promptly to calls for help (42.2\%). However, nearly close to as many respondents were also rather ambiguous on these two issues (37.8\%, 39.6\% respectively) suggesting that citizens may not be aware of how well they function. Overall, the findings suggest that college students were unsure of security guards' effectiveness in responding promptly to calls for help. 
Table 3: Citizen views on private security guards effectiveness $(N=800 ; N / \%)$

\begin{tabular}{|l|c|c|c|c|c|c|}
\hline \multicolumn{1}{|c|}{ Effectiveness } & N & Disagree & Neutral & Agree & Mean & S. D. \\
\hline Private Security Guards: & & & & & & \\
\hline Do a good job maintaining order & 752 & $151 / 20.1$ & $284 / 37.8$ & $317 / 42.2$ & 3.22 & 1.01 \\
\hline $\begin{array}{l}\text { Respond to citizens' call for help } \\
\text { in a timely manner }\end{array}$ & 750 & $135 / 18.0$ & $297 / 39.6$ & $318 / 42.2$ & 3.26 & 0.98 \\
\hline Perform their work effectively & 756 & $162 / 21.4$ & $301 / 39.8$ & $293 / 38.8$ & 3.17 & 0.97 \\
\hline
\end{tabular}

* Mean score on a 5-point scale ( 1 = strongly disagree to 5 = strongly agree $)$.

Source: Drawn by the author

\section{Views on Security Guards' Civility}

Respondents were also asked four questions to assess their views on how polite, fair and civil security guards were in their interactions with citizens. Findings are presented in Table 4. Overall, less than half of all the respondents believe that private PSGs are civil in their interactions with citizens. However, the findings suggest that there were as many people who were unsure about their civility as they agreed with this question. For instance, $40.3 \%$ agreed that private security guards treat citizens in a fair manner compared to $36.3 \%$ who were unsure. Findings were similar to other questions that attempted to capture the sense of private security guards' civility in their interactions with the citizens. Just over one third of the students reported that they believe security guards were civil on various dimensions such as the security guards' respect for citizens' rights (37.5\%), treating citizens with respect (37.8\%), making fair decisions when handling citizens' problems (34.9\%). These findings suggest that as many respondents were unsure about the private security guards' civility or fairness in their interactions with citizen as they agree with this concept.

Table 4: Citizen views on private security guards civility $(N=800 ; N / \%)$

\begin{tabular}{|l|c|c|c|c|c|c|c|}
\hline Civility & \multicolumn{2}{|c|}{ N } & \multicolumn{2}{|c|}{ Disagree } & \multicolumn{2}{c|}{ Neutral } & \multicolumn{2}{c|}{ Agree } & \multicolumn{2}{|c|}{ Mean } & $\begin{array}{l}\text { S. } \\
\text { D. }\end{array}$ \\
\hline Private Security Guards: & & & & & & \\
\hline Treat people fairly & 753 & $176 / 23.3$ & $273 / 36.3$ & $304 / 40.3$ & 3.16 & 1.01 \\
\hline Respect citizens' rights & 755 & $173 / 22.9$ & $299 / 39.6$ & $283 / 37.5$ & 3.12 & 0.99 \\
\hline Treat citizens with respect & 752 & $166 / 22.0$ & $302 / 40.2$ & $284 / 37.8$ & 3.15 & 0.99 \\
\hline
\end{tabular}




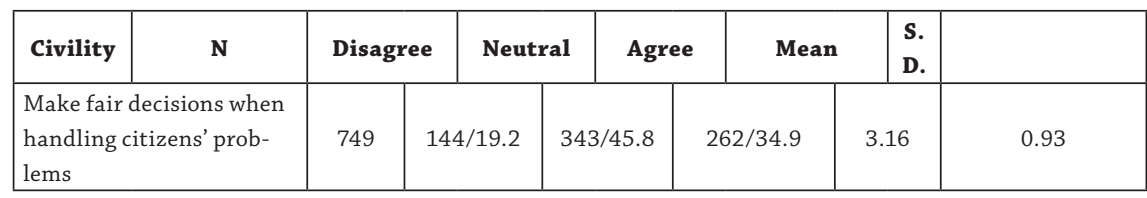

* Mean score on a 5-point scale ( 1 = strongly disagree to 5 = strongly agree).

Source: Drawn by the author

\section{Satisfaction with Private Security Guards}

Finally, we asked respondents how satisfied they were with private security guards overall. We asked ten questions that captured this dimension: whether security guards do a good job in working with people to solve problems, whether they provide good services that residents want, and among others, I am personally satisfied with their services. The findings are presented in Table 5. Overall, there has been a greater agreement among the residents on various dimensions of satisfaction from PSG services. Chief among them was that half of all of them felt that private security guards are helpful (50.1\%). Close to two-fifths agree that private security guards are courteous (41.9\%), provide the assistance citizens need (40.9\%), attentive to the needs of the people (38.5\%), that they are personally satisfied with guards, that guards take time to listen to people. Interestingly, however, just as many respondents indicated their uncertainty about their views on these matters, once again suggesting that many residents may not be in a position to assess private security guards.

Table 5: Citizen satisfaction with private security guards $(N=800 ; N / \%)$

\begin{tabular}{|l|c|c|c|c|c|c|}
\hline \multicolumn{1}{|c|}{ Satisfaction } & N & $\begin{array}{c}\text { Disag- } \\
\text { ree }\end{array}$ & Neutral & Agree & Mean & S. D. \\
\hline $\begin{array}{l}\text { Private Security } \\
\text { Guards: }\end{array}$ & 753 & $126 / 16.7$ & $250 / 33.2$ & $377 / 50.1$ & 3.37 & 0.98 \\
\hline Are helpful & 752 & $154 / 20.5$ & $283 / 37.6$ & $315 / 41.9$ & 3.23 & 1.00 \\
\hline $\begin{array}{l}\text { Are courteous to ci- } \\
\text { tizens they get into } \\
\text { contact }\end{array}$ & 750 & $135 / 18.0$ & $308 / 41.1$ & $307 / 40.9$ & 3.25 & 0.96 \\
\hline $\begin{array}{l}\text { Are able to provide } \\
\text { the assistance the } \\
\text { public needs from } \\
\text { them }\end{array}$ & 753 & $155 / 29.5$ & $308 / 40.9$ & $290 / 38.5$ & 3.16 & 0.95 \\
\hline $\begin{array}{l}\text { Are attentive to the } \\
\text { needs of people }\end{array}$ & & & & & & \\
\hline
\end{tabular}




\begin{tabular}{|l|c|c|c|c|c|c|}
\hline \multicolumn{1}{|c|}{ Satisfaction } & N & $\begin{array}{c}\text { Disag- } \\
\text { ree }\end{array}$ & Neutral & Agree & Mean & S. D. \\
\hline $\begin{array}{l}\text { I am personally } \\
\text { satisfied with their } \\
\text { services }\end{array}$ & 751 & $173 / 23.1$ & $290 / 38.6$ & $288 / 38.3$ & 3.14 & 1.07 \\
\hline $\begin{array}{l}\text { Take time to listen } \\
\text { to people }\end{array}$ & 752 & $152 / 20.2$ & $315 / 41.9$ & $285 / 37.9$ & 3.18 & 0.98 \\
\hline $\begin{array}{l}\text { Do a good job in } \\
\text { working with peop- } \\
\text { le to solve problems }\end{array}$ & 751 & $164 / 21.8$ & $305 / 40.6$ & $282 / 37.6$ & 3.15 & 0.99 \\
\hline $\begin{array}{l}\text { Provide good ser- } \\
\text { vice that residents } \\
\text { want }\end{array}$ & 753 & $167 / 22.1$ & $312 / 41.4$ & $274 / 36.4$ & 3.15 & 0.98 \\
\hline $\begin{array}{l}\text { Are sensitive to } \\
\text { people's concerns }\end{array}$ & 751 & $169 / 22.5$ & $315 / 42.2$ & $265 / 35.3$ & 3.13 & 0.97 \\
\hline $\begin{array}{l}\text { Do a good job in } \\
\text { working with peop- } \\
\text { le to solve problems }\end{array}$ & 750 & $196 / 26.2$ & $309 / 41.2$ & $245 / 32.6$ & 3.05 & 0.98 \\
\hline
\end{tabular}

* Mean score on a 5-point scale ( 0 = strongly disagree to 5= strongly agree).

Source: Drawn by the author

\section{Discussion and Conclusions}

The primary objective of this report on public perceptions of security guards in Hungary was to assess young Hungarians' perceptions of security guards' professionalism, effectiveness in their work, as well as their civility in their interactions with citizens. In addition, we also examined the extent to which youth are satisfied with services provided by security guards. For this study, we focused on youth, primarily college students' perceptions. Overall, our findings suggest that overwhelmingly, the youth's perceptions of private security guards appear to be more ambivalent and not overwhelmingly positive on various dimensions of security guards that include issues relating to professionalism, effectiveness and civility. Nevertheless, respondents answered more positively regarding their satisfaction with security guards' ability to take care of problems in the community. This finding may not come as a surprise given that security guards are employed by small businesses and the corporate sector to offer safety and security to owners and their clients. It may be worthwhile to consider a proper presentation of private security guards in the popular culture. PSGs are often portrayed in a demeaning manner in Hollywood movies (e.g. Armed and Dangerous) and TV programs. It is unclear if popular stereotypes may have had an impact on those who did not have contact with guards. Future research should control these effects when assessing contact.

These findings shed some light on important attributes of private police as they relate to professionalism, civility and general satisfaction. These are key ingredients by 
which agents of social control can garner support and cooperation in their work in dealing with order maintenance and crime prevention who in turn effectively function as "ears and eyes" of the public police.

While these findings cast some light on how youth perceive private security guards, we suggest that these findings be interpreted cautiously. This study has a small sample in one city, which does not represent the larger population. More importantly, we must recognize the historical and cultural context of the city, which experienced rapid growth in the last two decades, had seen a remarkable increase in business, housing, urbanization and migration from both rural and other smaller urban centres.

A second reason why we recommend exercising caution in interpreting the results is due to the sampling strategy. Clearly, greater resources are needed to generate a more representative and random sample to participate in research of this nature. The sample is also limited in size and focused on those who were born after the reconstitution of the independent Russian Federation from the Soviet Union in 1990. While this may have led to more randomness of the respondents who participated in the study, the degree of this randomness is less precise as can be expected in developed methodological deployment. On a positive note, we conclude that overall, young Hungarian citizens do not appear to be negative of personnel employed in the business of private policing (i.e. the private security guard industry). This is encouraging and suggests that public police can garner more positive relationships with private security guards in enhancing citizens' confidence in the state's social regulation and order functions. While our data does not directly support this conclusion, further research in this area is clearly warranted.

\section{BIBLIOGRAPHY}

Cao, Liqun - Zhao, Jihong S. (2005): Confidence in the police in Latin America. Journal of Criminal Justice, Vol. 33, No. 5. 403-412.

CoESS (2013): Private Security Services in Europe. Fact and Figures, 2015. Source: www.coess.org/newsroom.php?page=facts-and-figures (Downloaded: 26.06.2018.)

Christián László ed. (2014):.A magánbiztonság elméleti alapjai. [The Theoretical Basis of Private Security.] Budapest, National University of Public Service.

Nalla, Mahesh K. - Gurinskaya, Anna (2017): Common past - different paths: Exploring state regulationof private security industry in Eastern Europe and post-Soviet republics. International Journal of Comparative and Applied Criminal Justice, Vol. 41, No. 4. 305-321.

Nalla, Mahesh K. - Wakefield, Alison (2014): The security officer. In Gill, Martin ed.: The Handbook of Security. London, Palgrave Macmillan. 727-746.

Nalla, Mahesh K. - Gorazd Meško - Andrej Sotlar - Joseph Johnson (2006): Professionalism, Goals, and the Nature of Private Police in Slovenia. Journal of Criminal Justice and Security, Vol. 8, No. 3-4. 309-322.

Rettman, Andrew (2010): Private guards outnumber policemen in seven EU countries. EUobserver, Dec. 14. Source: https://euobserver.com/justice/31501 (Downloaded: 04.06.2018.) 
Shearing, Clifford D. - Stenning, Philip C. (1983): Private Security: Implications for Social Control. Social Problems, Vol. 30, No. 5. 493-506.

van Steden, Ronald - Nalla, Mahesh K. (2010): Citizen Satisfaction of Private Security Guards in the Netherlands: Perceptions of an Ambiguous Occupation. European Journal of Criminology, Vol. 7, No. 3. 214-234. 